\title{
OPINIONS ON MODERN METHODS, TECHNIQUES AND PROCEDURES OF FINANCIAL CONTROL USED IN ENTITIES OF THE MINISTRY OF NATIONAL DEFENCE
}

\author{
Marian JIANU \\ Control and Inspection Corps, Bucharest, Romania \\ jianumarian09@yahoo.com
}

\begin{abstract}
Financial control, as part of the internal managerial control and economic control, is also for the entities from the Ministry of National Defence an activity of major importance for the efficient, effective and economical use of the resources allocated to them. The own preventive financial control is also carried out in entities of the Ministry of National Defence based on a customized normative framework, starting from the one established for all public institutions. The set of methods for performing own preventive financial control in army units brings together, according to the special normative act adopted for this ministry, the specific framework of operations subject to own preventive financial control, the circulation schedule of documents verified in this control, specialized organizational compartments / entities in which the operations subject to this control are initiated and carried out. The Coronavirus pandemic that started in 2020 and continues in 2021 suggested the idea of running in a computerized, digitized system of own preventive financial control, to avoid or minimize direct contact between controllers and controlled, which is why we proposed the establishment of an appropriate computer system for such a purpose.
\end{abstract}

Keywords: control, own preventive financial control, the specific framework of the operations subject to own preventive financial control, specialized compartments, control procedure, visa refusal, management information systems

1. Defining elements regarding the organization and exercise of own preventive financial control in entities of the Ministry of National Defence

The organization of own preventive financial control in entities of the Ministry of National Defence is not only a very important and vital mission for the protection of material and financial resources allocated and used by these structures, but also a legal obligation, configured by specific regulations.

The normative acts, general and specific, that regulate this activity in the army units are OMPF no. 923/2014 [1], republished, for the approval of the General Methodological Norms regarding the exercise of preventive financial control and of the Specific Code of professional norms for the persons carrying out own preventive financial control activity, OMPF no. $103 / 2019$ [2] on amending and supplementing the Order of the Minister of Public Finance no. 923/2014 and Order of the Minister of National Defence (OMND) no. M 19/03.02.2018 [3] for the modification of the order no. M.120/19.11.2014 for the approval of the specific methodological Norms regarding the organization and exercise of the own 
preventive financial control in the Ministry of National Defence.

The own preventive financial control is organized by the authorizing officers, at the level of military units, by establishing the following organizational aspects:

- the specific framework of operations subject to own preventive financial control, the circulation schedule of documents provided in the specific framework and the organization of records budgetary commitments;

- the specialized organizational compartments/entities in which the operations subject to own preventive financial control are initiated and carried out;

- the persons with attributions and responsibilities in carrying out the operations subject to own preventive financial control;

- the persons who certify the reality, regularity and legality of the projects of operations subject to own preventive financial control;

- the persons who exercise, by visa, own preventive financial control and the identifier of the visa holder.

According to this specific normative act (OMND no. 19/2018) a distinct framework of operations subject to own preventive financial control was established.

The chief/similar accountants elaborate the project of the specific framework, the checklists of the control objectives, as well as the list of the normative acts applicable for each operation included in the projectand is analysed in a working meeting of the authorizing officer with all the persons involved and is approved by the authorizing officer.

The persons who exercise, by visa for own preventive financial control, are designated by the authorizing officers, by appointment order whose model is provided in Annex no. 5 to the present specific methodological norms [4]. The appointment of the persons exercising, by visa, own preventive financial control at the level of the tertiary authorizing officers is made following a procedure.

The appointment of the persons who exercise, by visa, own preventive financial control at the level of the secondary authorizing officers is made according to a procedure like the above, but also specific to this organizational level.

For the appointment of persons exercising, by visa, own preventive financial control at the level of the main authorizing officer, the procedure expressly provided in the Specific Code of Professional Norms for persons carrying out own preventive financial control activity, approved by Order of the Minister of Public Finance no. 923/2014 [5] and amended by the Order of the Minister of Public Finance no. 103/2019.

The practice of the activity in the field of own preventive financial control requires, unfortunately, also the recourse sometimes to the suspension, change or dismissal of the persons designated to exercise the activity of own preventive financial control. The situations in which the person designated to exercise own preventive financial control may be suspended, changed or dismissed are those expressly provided in the Specific Code of Professional Norms for the persons carrying out the activity of own preventive financial control.

A very important set of provisions in this normative act refers to the exercise of own preventive financial control. This control in the Ministry of National Defence is exercised by applying the provisions of the General Methodological Norms regarding the exercise of preventive financial control and the Specific Code of professional norms for the persons who carry out own preventive financial control activity.

Another very important component part of these specific methodological norms refers to the evaluation of the activity of the person exercising own preventive financial control. 
From the comparative analysis between OMPF no. 103/2019 and OMND no. M 19/03.02.2018 regarding the General Methodological Norms on the exercise of preventive financial control and the Specific Code of professional norms for persons carrying out own preventive financial control activity resultsthat the specific regulation for the army is not updated anddoes not include the changesbrought by OMPF no. 103/2019.

We have in mind the following changes that should be updated and customized to the specifics of the entities in the Romanian Army:

- In annex no. 1.1, in point B "Legal commitments resulting directly or indirectly, payment obligations", after the current number 20 three new current numbers are introduced;

- In the annex no. 1.1, in letter $\mathrm{F}$ "Checklists for operations included in the General Framework of operations subject to preventive financial control", after "Checklist of legal commitment (contract / agreement / financing agreement, grant agreement, loan agreement, etc.) for granting de minimis state aid", code B.20, three new checklists are introduced, checklists code B.21, B.22 and B.23;

- In the annex no. 1.1, at letter G "List of normative acts included in the second column of the General Framework of operations subject to preventive financial control", after the current number 105, three new current numbers are introduced, the current numbers 106 - 108;

- Annex no. 1.8 (concerning the Report on the activity of preventive financial control by month/quarter ... year ...) is amended and replaced by an annex with amended content; 5) It is introduced Chapter II -Synthesis of the motivations on which the visa refusals were based;

- It is introduced Chapter III Synthesis of operations refused a visa and carried out on the own responsibility of the head of the public entity;
- It is introduced Chapter IV Professional training of persons designated to perform preventive financial control. All these changes should be found in a variant adapted to the specific, in the new version of the normative act for the army, which should be adopted as soon as possible.

\section{Possible solutions for modernization and computerization of own preventive financial control in the Ministry of National Defence in the context of the Coronavirus pandemic}

From the above presented on the organization of own preventive financial control in the Ministry of National Defence and from the strategy of developing internal public financial control configured by the General Secretariat of the Government and the Ministry of Public Finance, we detached, as a possible action to be configured in the future to achieve an integrated IT system for the exercise of internal/managerial control and own preventive financial control, which would increase the operability and accuracy of such controls.

We present some essential aspects that computer scientists who would be involved in the development of such an integrated computer system should consider when designing such a system. We refer to the proposals that a computer scientist should consider when designing an integrated computer system, only for own preventive financial control (which is also the object of investigation of our article).

The expert system that should be introduced for the management of the necessary documents in the own preventive financial control process is a traditional one, being able to be based on the internal norms of the military institution, which establishes precise rules for any situation.

In order to achieve such a new integrated computer system, a project competition must be organized and the technical documentation, specifications and the 
selection competition itself must be carried out.

The realization of the project must be done according to the legislation on public sector procurement, and the competition of solutions and results will be published in the Official Gazette.

The proposed IT system must be developed in a modular design, which will allow the gradual integration of all IT systems to be developed along the way, using a single database, and the component modules will be created at the level of essential activities in the Ministry of National Defence units involved in preventive financial control activity.

Management information systems are being used more and more widely in Romanian companies. The need to introduce such a system in the units of the Ministry of National Defence where preventive financial control is performed, is motivated by the fact that the information must be correct and provided on time, both to management and operational levels, in order to increase the efficiency of internal financial control. In the contemporary world, characterized by dynamism, this is only possible using computational technology.

After finalizing the solution contest, you can actually move on to the design stage. The project will seek to raise the capacity of the Ministry of National Defence on two levels:

- implementation of an innovative solution, with a friendly interface that provides applications for the daily activities of all units involved in preventive financial control;

- adequate training of users.

The project could be composed of two parts: telecommunications infrastructure (workstations, servers, fixed and virtual local and territorial network, intranet, internet) and applications: the document management system.

The basic element of the intended document management system is the paper document, which does not allow close monitoring, nor does it allow users to access these documents online.

This application should be designed to replace paper by introducing a new basic eDocument. The system can work with different types of documents from different sources and in different formats. DMS (Document Management System) allows the structures of the Ministry of National Defence involved in organizing and conducting preventive financial control to define an optimal internal work cycle and to monitor each document on its path to a specific work cycle.

The electronic archive allows each user to access via the Internet or Intranet all the documents to which he has access.

Document Management System (DMS) can be an application with a web interface built on the IBM Lotus Notes/Domino platform or other types of platform suitable for such an application. Using an internal email server, the application can coordinate any activity specific to the Ministry of National Defence by managing all documents. The system must also include an electronic archiving module that stores and coordinates issues related to the form and structure of the decision documents.

Users have access via the Internet or intranet to the documents stored in this electronic archive, according to the level of security approved and the right to access certain documents.

The experience gained in other applications implemented in the Ministry of National Defence must be used, such as the one used for international missions, in which the army of our country has taken and will take part in the future [6].

An additional reason for designing and introducing such an application is the problems caused by the CORONAVIRUS pandemic that broke out in 2020 and continues into 2021, which has led to spatial distancing between co-workers and widespread use of homework or in the online environment, in order to avoid as 
much as possible, the direct contact in the work activities in public institutions and the private environment.

It is known that so far the activity of preventive financial control (own and delegated) involves the movement with documents on them of those who apply for VCF visas to persons authorized to grant such visas, circumstances that lead to direct contact between the two parties interacting in such activities

To ensure the use of this application at optimal parameters, general presentations, practical and specialized trainings, round tables for questions and comments, online support for operational and updating issues will be organized.

The implementation plan must go through five stages:

- Realization of the activity plan, stage in which: the system requirements and its architectural structure are established; the technical and functional specifications for the Document Management Application for preventive financial control are created; the foundations of the training plan are laid according to the requirements of those involved; the testing methodology is established and the module for extracting information from the old document storage system is provided;

- Customization of applications and completion of network infrastructure, stage in which: applications are customized according to standards and legislative requirements in the field of preventive financial control and particular requirements of structure and operation of the Ministry of National Defence; the local and virtual network is completed by installing workstations, servers and internet and intranet connection; the actual testing is performed according to the standards in the field of preventive financial control;

- Implementation, training and testing, stage in which: for DMS the pilot implementation is carried out in the departments and structures from the upper echelons and from the units where the preventive financial control is requested; support and assistance in use is provided; the results of the use are tested according to the specifications prepared for the acquisition of the company that designs and implements such an application;

- Completion of implementation, system integration and training, stage in which: the extension of DMS in all structures of the Ministry of National Defence involved in the organization and conduct of preventive financial control is performed; integrates through interoperability all applications provided to all structures involved; the final training is performed for all users;

- Monitoring the system and the guarantee offered by the supplier company, stage in which the system is supervised during the warranty period offered by the software company.

Types of documents involved in the application for preventive financial control would be the following:

- Accounting and budgetary documents;

- Public procurement documents;

- Expenditure ordering documents;

- Documents for the concession, rental, transmission, sale and exchange of goods from the patrimony of military units;

- Documents of other operations subject to own preventive financial control;

- Legal documents;

- Functions held by persons, who are involved in applying for and granting the preventive financial control visa;

- The specialized departments in which the operations subject to own preventive financial control are initiated and carried out;

- Functions held by persons, who are involved in solving the cases of refusal to grant the preventive financial control visa. 
A) Accounting and budgetary documents, permanently updated, according to the specific Methodological Norms from the Order of the Minister of National Defence no. M19/03.02.2018 - documents mentioned in operations and checklists (such as: budgets, requests for opening budget appropriations, budgetary provisions, documents for changing the quarterly allocation of budget appropriations, documents for making credit transfers, budgetary provisions on withdrawal of budget appropriations, formatted accounting documents - invoices; receipts; collection/ payment provisions; payment orders; payroll statements; etc. .; management accounting documents: consumption voucher; shipping notice; reception note and finding of differences; etc.; summary accounting documents: accounting registers - journal register; inventory register; general ledger; monthly checking balances; balance sheet; cash register; bank journals; etc.);

B) Public procurement documents, permanently updated, according to the specific Methodological Norms from OMND no. M19/03.02.2018 - documents mentioned in operations and checklists (such as: public procurement contracts; annual public procurement strategy; annual public procurement programs; public procurement program at project level - in case of projects financed from grants and/or research and development projects, complete award documentation, as published in the SEAP, clarifications to the award documentation, winning bids and clarifications related to the offers, if applicable; Contract/Decision /Financing order; application form, financing contract, partnership agreement, etc.);

C) Expenditure ordering documents, permanently updated, according to the specific Methodological Norms from OMND no. M19/03.02.2018 - documents mentioned in operations and checklists (such as: payment orders regarding public procurement, concession of works or services; contract/subsequent public procurement contract, or order, contract for concession of works or services; the document establishing the guarantee of good execution, the document constituting the reception commission, the documents regarding the reception, etc.; payment order for advances granted within the public procurement contract/concession of works or services; etc.);

D) Documents for the concession, rental, transmission, sale and exchange of goods from the patrimony of the military units, permanently updated, according to the specific Methodological Norms from OMND no. M19/03.02.2018 - documents mentioned in operations and checklists (such as: concession contract for public property - the military unit is the grantor, with the supporting documents; contract for renting public property - the military unit is the holder of the right ownership/administration, with the related supporting documents, works or services concession contract - the military unit is the grantor, with the related supporting documents; etc.);

E) Documents of other operations subject to own preventive financial control, permanently updated, according to the specific Methodological Norms from OMND no. M19/03.02.2018 - documents mentioned in operations and checklists (such as: contracting strategy for public procurement, with related supporting documents; contracting strategy for the concession of works or services, with related supporting documents; model framework agreement public procurement included in the award documentation, with the related supporting documents; etc.);

F) Legal documents according to the specific Methodological Norms from OMND no. M19/03.02.2018 - those from the List of normative acts included in the second column of the Specific Framework of operations subject to own preventive financial control, which must be permanently updated; 
G) Functions held by persons, who are involved in applying for and granting the preventive financial control visa:

- The main, secondary and tertiary authorizing officers of the Ministry of National Defence;

- The leaders/heads of the specialized departments from all the units and echelons in which the operations subject to own preventive financial control are initiated and carried out, as well as the subordinated personnel, with attributions in the administration of material goods or other values;

- Head of the General FinancialAccounting Directorate of the Ministry of National Defence;

- The leaders of the financialaccounting departments from categories of forces, central structures, large units and units;

- Persons designated to exercise preventive financial control (who meet the requirements of the Specific Code of Professional Norms for persons carrying out own preventive financial control activity, approved by Order of the Minister of Public Finance no. 923/2014);

- Administrators and chief accountants of economic operators under the coordination of the Ministry of National Defence;

- The heads of the legal/similar departments, for the operations that are approved, according to the law, by the legal, financial departments before being subjected to own preventive control.

I configured in Scheme no. 1 below, the mechanism for granting the preventive financial control visa.

\begin{tabular}{|l|}
\hline The heads of the legal/similar departments that approve operations subject to own preventive financial \\
\hline \multicolumn{1}{|c|}{$\Delta$} \\
\hline The heads of the financial-accounting departments and the persons designated to exercise \\
\hline $\begin{array}{l}\text { Leaders/heads of specializeddepartments in all units and echelons initiating preventive financial } \\
\text { control operations }\end{array}$ \\
\hline
\end{tabular}

Scheme no. 1: The mechanism for granting the preventive financial controlvisa Source: Own realization according to the specific Methodological Norms of the Order of the Minister of National Defence no. M19/03.02.2018

H) The specialized departments in which the operations subject to own preventive financial control are initiated and carried out:

- the microstructures of the military unit - compartments, offices, sections, services or other structures with attributions in initiating and carrying out operations subject to own preventive financial control;

- the microstructures from the military units financially insured by the military unit at the level of which the own preventive financial control is organized;

- the microstructures from the military units with attributions in initiating and carrying out some operationswhich, according to the law, are approved bythehierarchically superior credit officers and are subject to own preventive financial control.

I) Functions held by persons, who are involved in solving the cases of refusal to grant the preventive financial control visa:

- The persons designated to grant the preventive financial control visa who refused to grant the visa;

- The authorizing officer where the case of refusal to grant the preventive financial control visa appeared; 
- The internal public audit section in charge of which the military unit where the visa refusal case appeared;

- The delegated controller of the Ministry of Public Finance who is responsible for the Ministry of National Defence;

- The Court of Accounts of Romania. Of course, these are part of the opinions expressed by me, from the position of a professional in the financial-accounting field, who also performs preventive financial control, without claiming that I have exhausted the whole issue and the numerous particular situations that appear in the practice of exercising this activity of great responsibility in units of the Ministry of National Defence.

\section{Conclusions}

The own preventive financial control is also carried out in entities of the Ministry of National Defence based on a customized normative framework, starting from the one established for all public institutions and includes a set of methods for its implementation.

This set of methods brings together in a logical, coherent manner the specific framework of the operations subject to own preventive financial control, continuing with the circulation schedule of the documents verified in this control, the specialized organizational departments/entities in which the operations subject to this control are initiated and carried out and ending with the persons with attributions and responsibilities in the development and certification of the operations subject to own preventive financial control.

Following an analysis of the content of the normative act in force for the army entities (OMND no. M 19/03.02.2018) and the last one in force for all public institutions in our country (OMPF no. 103/2019), we concluded that the specific to the army must be updated with the novelty elements included in the 2019 normative act.

The Coronavirus pandemic that started in 2020 and continues in 2021 suggested the idea of running in a computerized, digitized system of own preventive financial control, to avoid or minimize direct contact between controllers and controlled, which is why we proposed the establishment of an appropriate computer system for such a purpose.

\section{References List}

[1] It was published in the Official Gazette of Romania, Part I, no. 28 / 15.01.2016.

[2] It was published in the Official Gazette of Romania, Part I, no. 87 / 04.02.2019.

[3] It was published in the Official Gazette of Romania, Part I, no. 214 bis / 09.03.2018.

[4] Subchapter 5.5. - "Persons certifying the reality, regularity and legality of the projects of operations subject to own preventive financial control", Chapter B - "Organization of own preventive financial control" from the specific Methodological Norms of the Order of the Minister of National Defence no. M 19/03.02.2018.

[5] Subchapter 5.6.-"Persons exercising, by visa, own preventive financial control", Chapter B -"Organization of own preventive financial control" from the specific Methodological Norms of the Order of the Minister of National Defence no. M19/03.02.2018.

[6] Popa N. Vasile N., Colonel Economist Associate Professor PhD Eng. Communication "Realizarea unui sistem informatic integrat pentru gestionarea documentelor unităţilo rministerului apărării implicate în misiuni internaționale", National Defence University "Carol I', Scientific communications session "Managementul integrat al resurselor de apărare. Necesitate, actualitate, perspective”, Brașov, December 14, 2007. 